УДК 658.7

\title{
МІЖНАРОДНІ ЛАНЦЮГИ ПОСТАВОК В УМОВАХ КОВІДНОЇ КРИЗИ
}

\section{INTERNATIONAL SUPPLY CHAINS IN THE CONDITIONS OF COVID-19 CRISIS}

\author{
Пасічник Тарас Олегович \\ кандидат економічних наук, \\ Університет митної справи та фрінансів \\ ORCID: https://orcid.org/0000-0002-7284-7345
}

Pasichnyk Taras

University of Customs and Finance

\begin{abstract}
Стаття присвячена вивченню основних проблем міжнародних ланцюгів поставок, спричинених кризою COVID-19, а також дослідженню перспектив розвитку логістичного управління за допомогою використання новітніх технологій. Показано, що пандемія COVID-19 стала причиною дисбалансу попиту і пропозиції на міжнародних ринках в останні декілька років, що суттєво вплинуло на ланцюги поставок і спричинило логістичну кризу у світі. Поступове відновлення темпів виробництва і пожвавлення міжнародної торгівлі призвели до поглиблення проблеми міжнародної логістики. Показана роль стратегічного планування і ризик-менеджменту в ефрективному реагуванні на системні збої у фрунціонуванні логістичних ланцюгів поставок. Виявлено, що майбутнє виходу з коронавірусної кризи у сорері логістики - за цифровими технологіями, такими як електронна комерція, відстеження в режимі реального часу, штучний інтелект. Для ефективного антикризового управління логістичними процесами компаніям важливо займатися постійним моніторингом за поточною ситуацією і оптимізувати внутрішні рутинні процеси в компанії.
\end{abstract}

Ключові слова: логістичні ланцюги поставок, COVID-19, логістичні технології, ризик-менеджмент.

Статья посвящена изучению основных проблем международных цепей поставок, вызванных кризисом COVID-19, а также исследованию перспектив развития логистического управления посредством использования новейших технологий. Показано, что пандемия COVID-19 стала причиной дисбаланса спроса и предложения на международных рынках в последние несколько лет, что существенно повлияло на цепи поставок и повлекло за собой логистический кризис в мире. Постепенное восстановление темпов производства и оживление международной торговли привели к углублению проблемы международной логистики. Показана роль стратегического планирования и риск-менеджмента в эффективном реагировании на системные сбои в фрункционировании логистических цепей поставок. Выявлено, что будущее выхода из коронавирусного кризиса в сфере логистики - за цифровыми технологиями, такими как электронная коммерция, отслеживание в режиме реального времени, искусственный интеллект. Для эффрективного антикризисного управления логистическими процессами компаниям важно заниматься постоянным мониторингом текущей ситуации и оптимизировать внутренние рутинные процессы компании.

Ключевые слова: логистические цепи поставок, COVID-19, логистические технологии, риск-менеджмент.

The article is devoted to the study of the main problems of international supply chains caused by the COVID-19 crisis, as well as the study of prospects for the development of logistics management through the use of new technologies. The COVID-19 pandemic has been shown to have caused an imbalance of supply and demand in international markets over the past few years, which has significantly affected supply chains and caused a global logistics crisis. The gradual resumption of production and the revival of international trade have exacerbated the problem of international logistics. Complex logistics system that transfers raw materials, components and products around the world requires predictability and accuracy - factors that have been lost. There was a shortage of transport containers, and prices for some routes have skyrocketed. It is revealed that today managers of the companies should solve the following problems of supply chains: imbalance of supply and demand in different segments, lack of supplies, problems of stock allocation, reduced productivity. For effective anti-crisis management of logistics processes, it is important for companies to monitor the current situation constantly and optimize internal routine processes in the company. It was found that during pandemic logistics companies focus on three main factors - security, cost-effec- 
tiveness and communication with customers. The role of strategic planning and risk management in the effective response to system failures in the functioning of logistics supply chains is shown. It is revealed that the future of overcoming the coronavirus crisis in the field of logistics is in digital technologies such as e-commerce, real-time tracking, artificial intelligence, digital supply network, the use of drones and parcel machines, omni-channel logistics. Digital technologies improve transparency of supply chains that is very important in conditions of anti-crisis management. Using new technologies improves communication between companies, customers and intermediaries, provides rapid response, improves asset efficiency, reduces costs and increases revenue of a company.

Keywords: logistics supply chains, COVID-19, logistics technologies, risk management.

Постановка проблеми. Минуло майже два роки 3 початку пандемії COVID-19, яка продемонструвала найбільш вразливі місця в ланцюгах поставок і створила новий складний ландшафрт для міжнародної торгівлі в усьому світі. Есрективне фрункціонування ланцюгів поставок завжди залежало від передбачуваного прогнозування попиту і пропозиції. Bсе змінилося з введенням національних лоқдаунів, і зараз ми спостерігаємо найбільшу турбулентність в логістиці за останні десятиліття.

Міжнародні ланцюги поставок, незважаючи на всі зусилля бізнесу і держав з подолання наслідків епідемії COVID-19, перебувають у кризовому стані, який особливо загострився в останні півроку. Структурні перекоси і диспропорції присутні на ринку контейнерів, в морській логістиці, роботі портів, в авіаперевезеннях, автомобільних та залізничних вантажоперевезеннях і навіть складській логістиці. В результаті диспропорцій виник дефріцит ключових виробничих компонентів (зокрема, світовий дефріцит мікрочипів [1]), не виконуються попередні замовлення, затримуються поставки, зростають транспортні витрати і споживчі ціни.

Аналіз останніх досліджень і публікацій. Питанням управління логістичною діяльністю компаній, побудови ефективних ланцюгів поставок займалися такі вчені, як П. Ларсон, Дж. Р. Сток, Д. Уотерс, П. Істон, Д. Ламберт, О. Вільямсон та інші. Новітні технології в логістичній сорері досліджувалися вченими Г. Хаасом, С. Грейвом, Я. Арлберном, Д. Флінтом, С. Вагнером та іншими. Щодо пандемії COVID-19 та її впливу на сучасну індустрію логістики, враховуючи безпрецедентну актуальність даної проблематики, сьогодні проводяться численні дослідження вченими-економістами всього світу. Разом з тим, зважаючи на складність досліджуваної теми, недостатньо вивченими залишаються питання управління виходом 3 логістичної кризи, а також ролі новітніх технологій в ефективному управлінні міжнародними ланцюгами поставок.

Метою статті $€$ вивчення основних проблем міжнародних ланцюгів поставок, спри- чинених пандемією COVID-19, а також дослідження перспектив розвитку логістичного управління за допомогою використання новітніх технологій.

Виклад основного матеріалу. Для розуміння причин сьогоднішньої логістичної кризи необхідно проаналізувати, як розвивалася міжнародна торгівля в останні два роки. Введення локдаунів у першій половині 2020 року призвело до зниження попиту на більшість споживчих товарів. Морські перевезення були скасовані, виробництва тимчасово призупинені, багато працівників залишилися без роботи.

Але, починаючи з літа 2020 року, завдяки великим фрінансовим стимулам урядів почав зростати імпорт у США та в інших розвинених країнах. Споживачі заполонили інтернетмагазини новими замовленнями, відновилось виробництво і торгівля, глобальна економічна машина знову ввімкнулась.

Справжні проблеми у фрункціонуванні ланцюгів поставок розпочалися наприкінці 2020 року. Перезапуск виробництв після локдаунів виявився нетривіальним 3 логістичної точки зору завданням. Складна логістична система, що переміщує сировину, комплектуючі та готову продукцію по всьому світу, вимагає передбачуваності і точності, але це було втрачено. Виник десріцит транспортних контейнерів, на деякі маршрути стрімко зросли тарифи (особливо з Китаю, Індонезії, Південної Кореї), утворилися затори в міжнародних портах, які потім поширилися на залізницю і внутрішні термінали. Імпортери зіштовхнулись із затримками в отриманні ключових виробничих компонентів, а експортери - 3 проблемами доступу до контейнерів та бронювання місця на морських суднах.

Важливою складовою світової торгівлі $\epsilon$ транспортні контейнери, в яких переміщують сировину, комплектуючі та готову продукцію 3 одного центру міжнародної торгівлі в інший. Стрімке зростання попиту після локдаунів, у поєднанні 3 низьким оборотом контейнерів, призвели до різкого зростання цін на морські перевезення (див. рис. 1). 


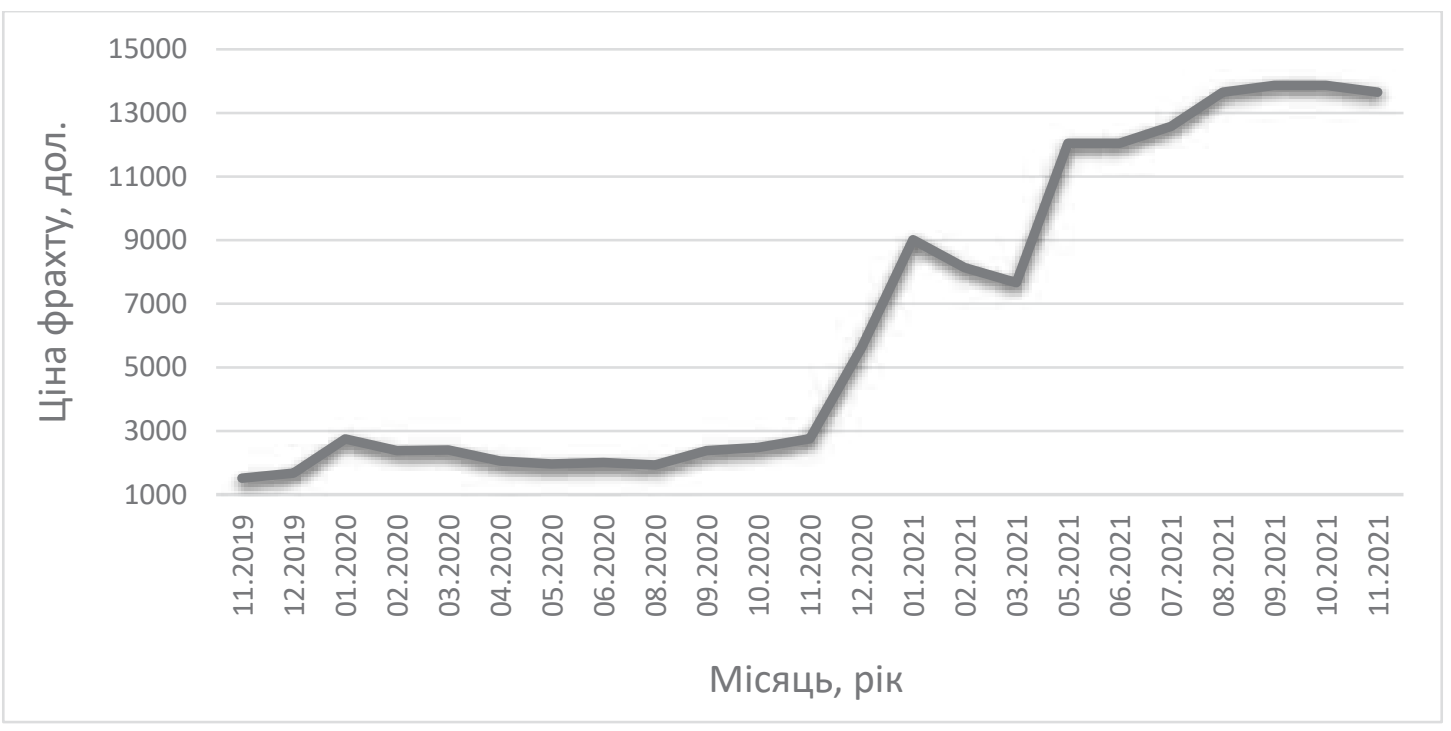

\begin{abstract}
Рис. 1. Динаміка ставок морського фррахту контейнерів 40НС в Україну 3 країн Дальнього Сходу (Китай, Південна Корея, Таїланд, Тайвань, Індонезія, Малайзія) з 11.2019 р. по 11.2021 р.
\end{abstract}

Джерело: складено автором

Складною логістичною проблемою стало повернення контейнерів до виробничих локацій, як правило, на зворотному шляху контейнери прямують порожніми. Багато контейнерів, в яких перевозили медичні маски до країн Афррики та Південної Америки на початку пандемії, перевізники не забрали назад, оскільки спрямували морські судна на найбільш вигідні маршрути Азія - Північна Америка / Європа. Іншими словами, в обігу стало менше контейнерів, що створило дисбаланс попиту та пропозиції на цьому ринку.

Додатковою причиною зростання ціни фррахту стало перекриття Суецького каналу судном «Ever Grand» у березні 2021 року, а також закриття ключового порту на півдні Китаю у травні-червні 2021 року, внаслідок чого зупинився рух 350 тис. контейнерів. Блокування Суецького каналу призвело до затримок поставок, багатьом суднам довелося обходити Афррику через південний шлях.

Стала очевидною потреба у підвищенні існуючої потужності морського транспорту, розміщуються замовлення на нові торгівельні судна, але вони будуть готові щонайменше у 2023 році. Окрім цього, існуюча тенденція до будівництва все більших за об'ємом суден створює проблеми з інфрраструктурою в портах та можливостями їх обслуговування. Кораблі стали вдвічі і навіть втричі більшими, ніж на початку 2000-х років, і тепер вміщують понад 20 тис. контейнерів.
Допоки існуватиме подібний дисбаланс обороту морських контейнерів, ціни на фррахт не нормалізуються, а це означає, що ціни на імпортні товари для населення будуть тільки зростати.

Для знаходження шляхів виходу з логістичної кризи необхідно проаналізувати виклики в логістичній сорері, спричинені пандемією. COVID-19 не є звичайним фактором ризику чи навіть форс-мажором. Масштаб його впливу більший за все те, з чим більшість менеджерів з логістики зустрічались раніше. Швидкість ескалації потребує безперервної оцінки поточної ситуації, оптимізації процесів і моніторингу. Компаніям необхідно швидко і впевнено реагувати, щоб сорормувати і виконати короткостроковий тактичний план, який знизить ризики для здоров'я людини і захистить налагоджені логістичні зв'язки. При цьому надійні дані і аналітичні можливості компаній мають вирішальне значення для розуміння складності проблем, прогнозування потенційних збоїв і швидкого реагування виклики, що постають.

Підприємства повинні вирішувати фрінансові та операційні проблеми таким чином, щоб водночас швидко задовольняти потреби своїх працівників, клієнтів і постачальників. Правильні дії, спрямовані на подолання наслідків кризи, несуть потенціал для структурних змін і пристосування до нової реальності.

Реагування на системні збої у функціонуванні логістичних ланцюгів поставок передбачає послідовне виконання наступних дій. 
Мобілізація

Аналіз

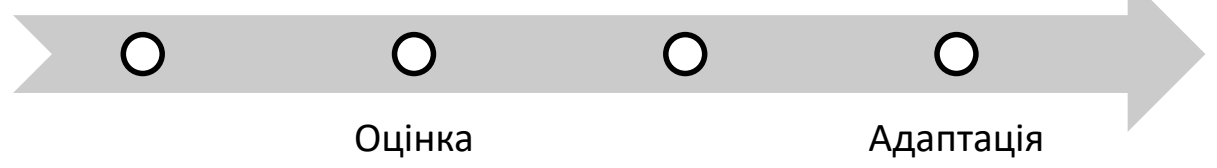

Рис. 2. Алгоритм реагування менеджменту компанії на кризові ситуації у функціонуванні ланцюгів поставок

1. Мобілізація командного центру та підготовка початкового плану реагування на кризу. Встановлення операційних правил для реагування на ситуації, пов'язані з непередбаченим втручанням у ланцюги поставок та управлінням ними у надзвичайних ситуаціях.

2. Розстановка пріоритетів в контексті реагування на нові ризики, оцінка наслідків як для цілої екосистеми, так і для окремих складових ланцюга поставок.

3. Аналіз сценаріїв «що, якщо» і підготовка протоколів дій у різних ситуаціях.

4. Конорігурація та налаштування інфоормаційних і товарних потоків під виконання заготовлених протоколів. Розробка збалансованої системи показників для моніторингу і вимірювання зусиль.

Пандемія COVID-19 - це не звичайна короткострокова криза. Вона має довгострокові наслідки як для роботи людей, так і для фрункціонування ланцюгів поставок. Компаніям вкрай необхідно забезпечити довгострокову стійкість своїх систем для можливості вирішення майбутніх проблем. Це потребує цілісного підходу до управління ланцюгами поставок, компанії повинні бути достатньо гнучкими в ході прийняття управлінських рішень. Такий підхід повинен грунтуватися на новітніх технологіях і платорормах, які підтримують прикладну аналітику, штучний інтелект і машинне навчання. Він також повинен забезпечувати наскрізну прозорість всього ланцюгу поставок. У довгостроковій перспективі реагування на ризики повинно стати невід'ємною частиною звичайних протоколів.

Сьогодні менеджерам компаній доводиться вирішувати наступні проблеми ланцюгів поставок, пов'язані з пандемією:

1) різкі стрибки попиту в сегментах (падіння і зростання);

2) нестача поставок;

3) проблеми розміщення запасів;

4) зниження продуктивності.

Есрективне кризове управління передбачає прийняття невідкладних пріоритетних рішень після виявлення проблеми, і щодо ланцюгів поставок такими пріоритетами є: а) найголовніше - це люди. Необхідно підтримувати здоров'я і продуктивність працівників, знаходити можливості для безперебійної роботи організації;

б) використання даних для забезпечення прозорості попиту, запасів, виробничих потужностей, пропозиції і фрінансів у системі;

в) сегментація ринку для визначення пріоритетного попиту;

г) створення антикризових команд з продажів та операційної роботи, які здатні ефективно виконувати поставлені завдання та відповідати на поставлені виклики;

д) моделювання і оцінка різних сценаріїв ланцюга поставок. Важливо моделювати, щоб передбачити, коли і де можуть виникнути надлишки і нестача, а також для отримання первинної інорормації, яка оптимізує операційні метрики.

Оцінюючи перспективи виходу з коронавірусної кризи, варто зазначити, що майбутнє за цифровими технологіями. Відповідно до звіту міжнародної аудиторської компанії PricewaterhouseCoopers за 2018 рік, компанії, які активно інвестують у цифррові технології, можуть очікувати зростання доходів на 25\% до 2023 року проти 9\% для компаній, що не планують інвестувати в діджитал [6]. Незважаючи на те, що над цим звітом працювали ще до пандемії, його висновки відповідають і сьогоднішнім умовам. Ось декілька цифррових інструментів, які можна використовувати для посилення ланцюгів поставок:

1) електронна комерція. На тлі сповільнення економічної активності пандемія призвела до сплеску електронної комерції та прискорення цифррової трансформації. Після того як карантинні заходи стали новою «нормальністю», підприємства та споживачі значно активніше почали переходити на «цифрові технології», пропонуючи та купуючи більше товарів і послуг онлайн, підвищивши частку електронної комерції у світовій роздрібній торгівлі з 14\% у 2019 році до приблизно 17\% у 2020 році [7];

2) відстеження в режимі реального часу. Трекінг вантажів, автоматизовані склади, GPS 
(система глобального позиціювання) і RFID (радіочастотна ідентифрікація) - це технології, які дозволяють відстежувати переміщення персоналу, обладнання і запасів, збирати дані і покращувати видимість та прозорість ланцюгів поставок;

3) подолання логістичних перешкод за допомогою технологій штучного інтелекту (Al). У логістиці штучний інтелект використовується для аналізу та вибору найшвидших і найдешевших маршрутів доставки. Крім того, існують такі технології, як автоматизована система управління піддонами, призначена для скорочення часу обробки відправлень. Така система дозволяє повністю автоматизувати процеси зберігання піддонів, транспортування завантажених піддонів та їх інтеграцію із складськими і виробничими процесами. Автоматизовану систему управління піддонами можна використовувати в транспортних вузлах, а також на орабриках, складах і розподільних центрах;

4) цифрова мережа постачання. Традиційну мережу постачання можна перетворити в більш відкриту та доступну цифррову мережу постачання (DSN), що працює на основі штучного інтелекту, аналітики, робототехніки, датчиків та алгоритмів. DSN збирає дані фрізичної реальності, створює їх цифрровий запис і дозволяє обмінюватися інформацією, аналізувати іiі та, в результаті, перетворювати в дію, яку можна здійснити в реальному світі. Така технологія покращує зв'язок між зацікавленими сторонами, забезпечує швидке реагування, сприяє підвищенню ефективності активів, знижує витрати та збільшує доходи компанії.

Висновки. Вирішення проблем у сфрері логістики, зумовлених пандемією COVID-19, лежить у площині стратегічного управління, ефективного ризик-менеджменту, а також використання інновацій. Цифррові технології забезпечують прозорість як усього ланцюга поставок загалом, так і окремих його елементів, дозволяють ефрективніше визначати зони потенційного ризику, вносити корективи до моменту виникнення проблеми, швидше реагувати на збої, якщо вони все-таки трапляються.

Технології логістики майбутнього повинні вирішувати завдання безпеки і стабільності, а також економічної ефективності компаній. Серед них найбільш затребуваними будуть бізнес-аналітика, штучний інтелект, мобільні технології і додатки, безпілотні транспортні засоби і дрони, цифррові мережі постачання, омніканальна логістика.

\section{СПИСОК ВИКОРИСТАНИХ ДЖЕРЕЛ:}

1. Світовий дефіцит мікрочипів у розпалі: як зростуть ціни на техніку та авто. Економічна правда. 2021. URL: https://www.epravda.com.ua/publications/2021/07/12/675833 (дата звернення: 12.12.2021).

2. The coronavirus' impact on the global automotive supply chain. Process Integration and Optimization for Sustainability. Forbes. 2020. URL: https://www.forbes.com/sites/laurieharbour1/2020/03/13/the-coronavirus-impacton-the-global-automotive-supply-chain/\#2f607021444е (дата звернення: 12.12.2021).

3. Haren P., Simchi-LeviD. Howcoronavirus could impacttheglobalsupply chain by mid-March. URL:https://hbr.org/ 2020/02/how-coronavirus-could-impact-the-global-supply-chain-by-mid-march (дата звернення: 12.12.2021).

4. Impact of COVID-19 crisis on industrial production. Eurostat : веб-сайт. URL: https://ec.europa.eu/eurostat/ statistics-explained/index.php?title=Impact_of_COVID-19_crisis_on_industrial_production (дата звернення: 12.12.2021).

5. Coronavirus: impact on the transportation and logistics industry worldwide - statistics \& facts. URL: https://www.statista.com/topics/6350/coronavirus-impact-on-the-transportation-and-logistics-industry-worldwide/ \#dossierKeyfigures (дата звернення: 12.12.2021).

6. How do you transform your supply chain into an intelligent, digital ecosystem? URL: https://www.pwc.com/us/ en/services/consulting/risk-regulatory/connected-supply-chain.html (дата звернення: 12.12.2021).

7. How COVID-19 triggered the digital and e-commerce turning point. Конфреренція $\mathrm{OOH} з$ торгівлі та розвитку. URL: https://unctad.org/news/how-COVID-19-triggered-digital-and-e-commerce-turning-point

\section{REFERENCES:}

1. The Global shortage of microchips is in full swing: how prices for equipment and cars will rise. Economic Pravda. Available at: https://www.epravda.com.ua/publications/2021/07/12/675833 (accessed 12 December 2021).

2. The coronavirus' impact on the global automotive supply chain. Forbes. Available at: https://www.forbes.com/ sites/laurieharbour1/2020/03/13/the-coronavirus-impact-on-the-global-automotive-supply-chain/\#2f607021444e (accessed 12 December 2021).

3. Haren P., Simchi-Levi D. How coronavirus could impact the global supply chain by mid-March. Available at: https://hbr.org/2020/02/how-coronavirus-could-impact-the-global-supply-chain-by-mid-march (accessed 12 December 2021). 
4. Impact of COVID-19 crisis on industrial production (2020). Eurostat. Available at: https://ec.europa.eu/ eurostat/statistics-explained/index.php?title=Impact_of_COVID-19_crisis_on_industrial_production (accessed 12 December 2021).

5. Coronavirus: impact on the transportation and logistics industry worldwide - statistics \& facts. Available at: https://www.statista.com/topics/6350/coronavirus-impact-on-the-transportation-and-logistics-industry-worldwide/ \#dossierKeyfigures (accessed 12 December 2021).

6. How do you transform your supply chain into an intelligent, digital ecosystem? Available at: https://www.pwc.com/ us/en/services/consulting/risk-regulatory/connected-supply-chain.html (accessed 12 December 2021).

7. How COVID-19 triggered the digital and e-commerce turning point. United Nations Conference on Trade and Development. Available at: https://unctad.org/news/how-COVID-19-triggered-digital-and-e-commerce-turning-point (accessed 12 December 2021). 